Article

\title{
Recycling of Spent Pot Lining First Cut from Aluminum Smelters by Utilizing the Two-Step Decomposition Characteristics of Dolomite
}

\author{
Yifei Wang, Xiping Chen *, Shaojun Zhang and Peixu Yang * \\ School of Material Science and Engineering, Zhengzhou University, Zhengzhou 450001, China; \\ 13676996694@163.com (Y.W.); zhangshaojun@zzu.edu.cn (S.Z.) \\ * Correspondence: chenxiping@zzu.edu.cn (X.C.); yangpx@zzu.edu.cn (P.Y.)
}

Received: 11 October 2020; Accepted: 16 November 2020; Published: 22 November 2020

\begin{abstract}
Spent Pot Lining First Cut (shortened to SPL-1cut) is a solid waste discharged from a primary aluminum electrolytic production process. SPL-1cut is classified as hazardous waste in China because it contains large amounts of soluble sodium fluoride and a tiny amount of cyanide. Most of SPL-1cut is carbon-about $65 \%$-and its calorific value is $22.587 \mathrm{MJ} \cdot \mathrm{kg}^{-1}$. There is a high level of sodium fluoride in SPL-1cut-about $15 \%$-and sodium fluoride is randomly distributed in the carbon granule. The recycling of SPL-1cut using dolomite as a reactant, based on the characteristics of the two-step decomposition of dolomite at a high temperature, is discussed. The recycling of SPL-1cut was performed under the following heating conditions: the heating temperature was $850{ }^{\circ} \mathrm{C}$, the holding time was $120 \mathrm{~min}$, and $40 \%$ of the dolomite was added to the SPL-1cut. It was found that the cyanides are completely oxidized and decomposed, and dolomite is decomposed into $\mathrm{MgO}$ and active $\mathrm{CaCO}_{3}$. At the same time, $\mathrm{NaF}$ reacts with active $\mathrm{CaCO}_{3}$ and converts into $\mathrm{CaF}_{2}$. The results provide references for using SPL-1cut as an alternative fuel in the dolomite calcination process of the Pidgeon Process.
\end{abstract}

Keywords: Spent Pot Lining First Cut; dolomite; Pidgeon Process; recycling

\section{Introduction}

The alumina-cryolite molten salt electrolysis process is currently the most mature industrial-scale primary aluminum production method and is widely used throughout the world. The production of primary aluminum from molten salt electrolysis has brought about some environmental problems, among which spent pot lining (SPL) is one of the most prominent. The service life of aluminum electrolytic cells is generally $5-8$ years [1,2]. About $30 \mathrm{~kg}$ of SPL is discharged per tonne of primary aluminum produced [2]. SPL is mainly composed of first cut materials (carbon-rich) and second cut materials (refractory-rich), of which SPL first cut (shortened to SPL-1cut) account for about $30-50 \%$ of the total mass [3]. Per tonne of primary aluminum, about 10-15 kg of SPL-1cut is generated as a by-product [4]. SPL-1cut is the most major hazardous waste from smelters, mainly containing carbon and sodium fluoride. SPL-1cut contains a large fraction of carbon (about 65\%); a high level of sodium fluoride (about 15\%); and small amounts of cryolite, calcium fluoride, alumina, and other substances [5]. SPL-1cut contains potential carbon energy and fluorine, which has important utilization value $[6,7]$. How to effectively recycle SPL-1cut has become a prominent problem which is being focused upon by the whole aluminum industry. In recent years, the rapid development of metallurgy, material design, and functionalization has provided a strong support for the recycling of industrial waste [8-10].

The toxicity of SPL-1cut is mainly due to soluble fluorides and cyanides. The content of fluorides in SPL-1cut is relatively high, and the most common type of them are sodium fluoride. Sodium fluoride 
is easily soluble in water, causing serious pollution to water resources and soils and easily forming high-fluorine water and high-fluorine soil, which in turn endangers the growth and survival of animals and plants. When cyanides meet water, they will release the harmful gas $\mathrm{NH}_{3}$. Heating at a high temperature is the simplest and most effective way to eliminate cyanides, which begin to decompose when heated to above $400{ }^{\circ} \mathrm{C}[11,12]$. In general, by adding a certain amount of $\mathrm{CaCO}_{3}$ in a high-temperature environment, the soluble $\mathrm{NaF}$ in SPL can be converted into stable $\mathrm{CaF}_{2}$, reducing the harm of soluble fluoride sharply. In previous studies, limestone was used to convert harmful fluorides into harmless and stable fluorides $[11,13,14]$. However, when limestone is used as a reactant to turn soluble fluorides into stable fluorides at a high processing temperature, some negative effects appear, such as the final product easily agglomerating and adhering to the furnace lining, so an anti-adhesive additive needs to be added. Reynolds Metals Company disclosed a method for treating SPL at a temperature of $650-930{ }^{\circ} \mathrm{C}$ using limestone and adding a certain amount of metal silicates [13]. Therefore, it is necessary to find a new reactant to treat SPL.

Dolomite is a kind of natural ore, and its main component is $\mathrm{CaMg}\left(\mathrm{CO}_{3}\right)_{2}$. Dolomite, after crushing and calcining, is an important raw material for the silicon thermal process of magnesium (the Pidgeon Process). $\mathrm{MgCO}_{3}$ and $\mathrm{CaCO}_{3}$ in dolomite exists in the structure of double salt with a strong binding force [15], and its decomposition temperature is higher than that of the $\mathrm{CaCO}_{3}$ in limestone. It is interesting that dolomite has the characteristics of two-step decomposition at high temperatures and fluorite is used as a catalyst in the Pidgeon Process [16,17]. $\mathrm{CaF}_{2}$ is mainly derived from natural fluorite, which is scarce in China. The use of natural fluorite is one of the reasons for the high cost of the Pidgeon Process. Based on the characteristics of the SPL-1cut and dolomite, some interesting experiments are put forward. What will happen if a certain amount of dolomite is added to the SPL-1cut at a high temperature? The following experimental results are expected: $\mathrm{CaCO}_{3}$ in the dolomite can convert fluorides into $\mathrm{CaF}_{2}$; toxic and harmful substances such as cyanides, nitrides, and carbides in the SPL-1cut can be eliminated at high temperatures; at the same time, the carbon in the SPL-1cut is fully burned at high temperatures to generate heat and provide reaction energy.

\section{Composition and Performance of SPL-1cut}

The SPL-1cut samples used in the experiments were taken from the newly shut-down aluminum reduction pots, which belong to three different smelters located in northwest, southwest, and central China with line currents of 400-500 kA. The service age of these pots was between 5 and 7 years. Three kinds of SPL-1cut were crushed by a hammer crusher s (SP-200, Tianyuan Instrument, Hebi, China) and fully mixed according to the mass ratio of 1:1:1, and then the mixed sample was ground by a ball mill and stored in an airtight plastic bucket for subsequent tests and experiments. X-Ray Diffractomer (XRD) (XRD-6100, SHIMADZU CORPORATION, Kyoyo, Japan), scanning electron microscope (SEM) (FEI-Quanta-250, FEI Quanta, Hillsboro, OR, USA), a calorimeter (5E-C5500,Changsha Kaiyuan Instruments, Changsha, China), and a sulfur analyzer (5E-AS3200B, Kaiyuan Instruments, Changsha, China) were used for identifying the physical and chemical properties of SPL-1cut. The phase composition of SPL-1cut is shown in Figure 1, and the micro-morphology is shown in Figure 2.

The matrix of the SPL-1cut is carbon and contains sodium fluoride, calcium fluoride, alumina, cryolite, and other components (as shown in Figure 1). The content of sodium fluoride is the highest among fluorides. Sodium fluoride has a high abundance and a wide-scale distribution in SPL-1cut (as shown in Figure 2a). There is a clear boundary between sodium fluoride and the carbon matrix (as shown in Figure 2b), so sodium fluoride and carbon can be initially separated by suitable processing.

The calorific value and sulfur content are, respectively, listed in Tables 1 and 2.

The calorific value of the SPL-1cut is relatively high, with an average value of $22.587 \mathrm{MJ} \cdot \mathrm{kg}^{-1}$, which is about $77.9 \%$ that of standard coal (as shown in Table 1). During the test, it was found that some white solid substances adhered to the inner wall of the test crucible and some gray solid substances were taken out of crucible. The reason for this phenomenon is that SPL-1cut contains a certain amount of non-combustible components such as fluorides. A small amount of fluoride-carbon mixture was 
taken out by gas flow when the $\mathrm{CO}_{2}$ gas rapidly escaped from the SPL-1cut, but the fluorides condensed again on the inner wall of the crucible during the combustion. The calorific value of SPL-1cut has good reproducibility via using aluminum foil to coat the sample.

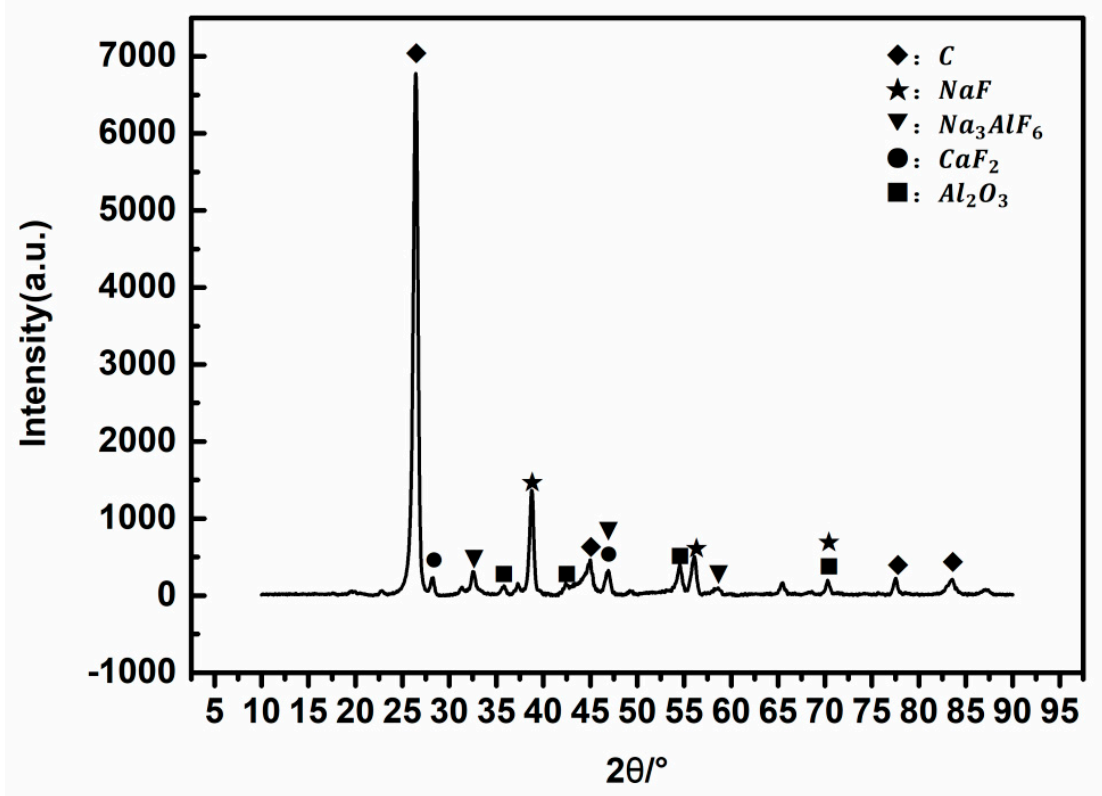

Figure 1. XRD pattern image of Spent Pot Lining First Cut (SPL-1cut).

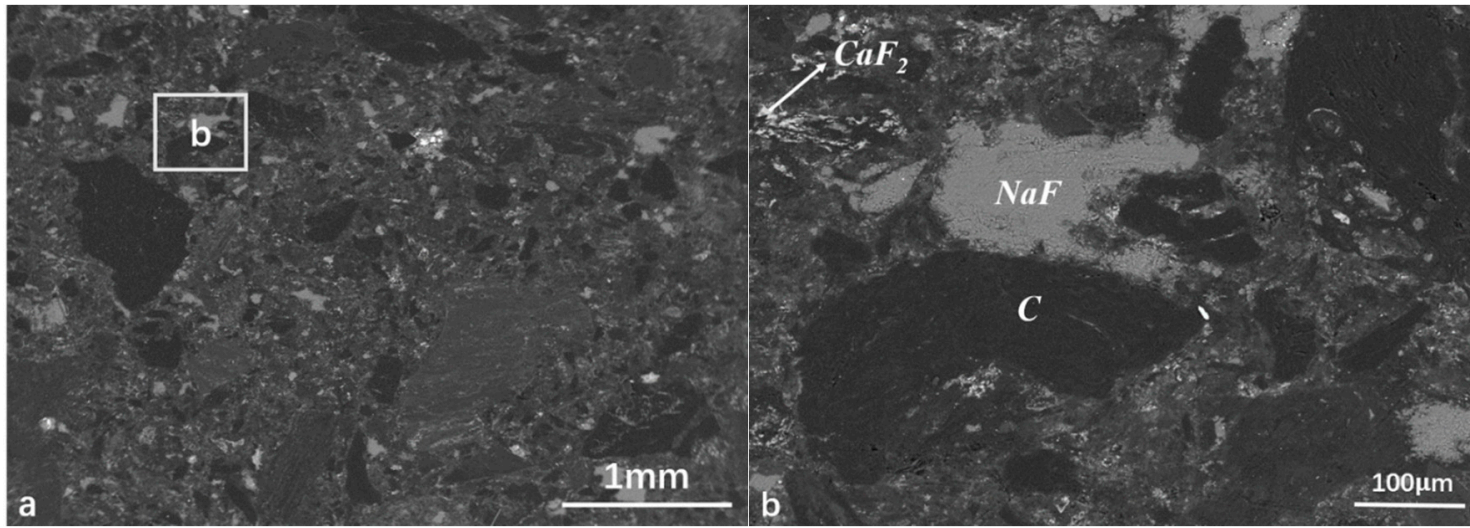

Figure 2. SEM-EDS analysis of SPL-1cut. (a) the microstructure of SPL-1cut; (b) enlarged view of the $\mathrm{b}$ area.

Table 1. The calorific value of SPL-1cut $\left(\mathrm{MJ} \cdot \mathrm{kg}^{-1}\right)$.

\begin{tabular}{ccc}
\hline Parallel Samples & Not Coated & Coated \\
\hline $\mathbf{1}$ & 21.389 & 22.718 \\
$\mathbf{2}$ & 22.099 & 22.359 \\
$\mathbf{3}$ & 21.670 & 22.683 \\
\hline
\end{tabular}

Table 2. Sulfur content of SPL-1cut (\%).

\begin{tabular}{cc}
\hline Parallel Samples & SPL-1cut \\
\hline $\mathbf{1}$ & 0.16 \\
$\mathbf{2}$ & 0.16 \\
$\mathbf{3}$ & 0.15 \\
\hline
\end{tabular}


The content of sulfur in SPL-1cut is relatively low (as shown in Table 2). When SPL-1cut is burned as an alternative fuel, the $\mathrm{SO}_{2}$ emissions will be sharply reduced and cause a small harmful impact on the regional environment.

The dolomite used in the experiment is a high-quality dolomite ore which was taken from Shanxi Province, China. It was processed by a jaw crusher (EP-II, Qitian Instrument, Hebi, China) and a ball mill (BYT-XGB4, Boyuntong Instruments, Nanjing, China) to obtain a suitable powder. The chemical components of dolomite are shown in Table 3.

Table 3. Chemical composition of dolomite.

\begin{tabular}{cccccc}
\hline Chemical Composition & $\mathrm{CaO}$ & $\mathrm{MgO}$ & $\mathrm{Al}_{\mathbf{2}} \mathrm{O}_{3}$ & $\mathrm{Fe}_{2} \mathrm{O}_{3}$ & $\mathrm{CO}_{2}$ \\
\hline Content (\%) & 31.22 & 22.31 & 0.05 & 0.05 & 47.04 \\
\hline
\end{tabular}

\section{Experimental}

SPL-1cut and dolomite were crushed and sieved separately, mixed according to a certain ratio, and loaded into corundum crucibles $(70 \times 70 \times 50$, Boyuntong Instruments, Nanjing, China), then crucibles with the experimental sample were placed in an ultra-high-temperature muffle furnace (QSH-1700M, Boyuntong Instruments, Nanjing, China) for heat treatment. The purpose of the experiments was mainly to eliminate cyanides in SPL-1cut and to obtain a high conversion ratio of fluoride. The experimental temperature was $750-950{ }^{\circ} \mathrm{C}$, the particle size of the sample was in the range of 0-200 mesh, the residence time was 90-210 $\mathrm{min}$, and the mass ratio of dolomite in the experimental sample was from 10 to $50 \mathrm{wt} \%$. The influences of the temperature, the particle size of the sample, the residence time, and the weight ratio of dolomite on the reaction loss ratio were studied.

The main reactions during the heat treatment were the combustion of carbon and the reactions between fluoride and dolomite (as shown in reactions 1, 2, 3, 4).

$$
\begin{gathered}
\mathrm{C}+\mathrm{O}_{2}=\mathrm{CO}_{2} \\
\mathrm{CaMg}\left(\mathrm{CO}_{3}\right)_{2}=\mathrm{CaCO}_{3}+\mathrm{MgO}+\mathrm{CO}_{2} \\
\mathrm{CaMg}\left(\mathrm{CO}_{3}\right)_{2}+2 \mathrm{NaF}=\mathrm{CaF}_{2}+\mathrm{Na}_{2} \mathrm{CO}_{3}+\mathrm{MgO}+\mathrm{CO}_{2} \\
6 \mathrm{CaMg}\left(\mathrm{CO}_{3}\right)_{2}+2 \mathrm{Na}_{3} \mathrm{AlF}_{6}=6 \mathrm{CaF}_{2}+3 \mathrm{Na}_{2} \mathrm{CO}_{3}+6 \mathrm{MgO}+\mathrm{Al}_{2} \mathrm{O}_{3}+9 \mathrm{CO}_{2}
\end{gathered}
$$

The combustion of carbon not only causes a large loss of the total weight of the sample but also causes more closer contact between fluoride and $\mathrm{CaCO}_{3}$, which helps promote the conversion of fluoride.

In order to identify which condition is better, the reaction loss ratio $\mathrm{Y}$ is used to visually judge the experimental results.

$$
\mathrm{Y}=\left(\mathrm{g}_{1}-\mathrm{g}_{2}\right) / \mathrm{g}_{1} \times 100 \%
$$

where $g_{1}$ is the initial weight of the mixed sample and $g_{2}$ is the weight of the final product after processing.

\section{Results}

Different experiments were carried out under different experimental conditions according to the preset experimental scheme. Experimental results are shown in Figure 3. In order to facilitate the analysis of the experimental results, we set $Y_{0}$ as the optimal loss ratio, which only includes the carbon burning loss and the decomposition loss of magnesium carbonate in dolomite during the thermal treatment; $\mathrm{Y}_{\mathrm{MAX}}$ is the maximum loss ratio, which is the complete combustion loss ratio of SPL-1cut 
plus the complete decomposition loss ratio of dolomite. SPL-1cut did not react with the dolomite during the process.

$$
\begin{gathered}
\mathrm{Y}_{0}=\left[\left(\mathrm{g}_{1} \times \mathrm{c}_{1} \times \mathrm{Y}_{1}\right)+\left(\mathrm{g}_{1} \times \mathrm{c}_{2} \times \mathrm{Y}_{3}\right)\right] / \mathrm{g}_{1} \times 100 \% \\
\mathrm{Y}_{\mathrm{MAX}}=\left[\left(\mathrm{g}_{1} \times \mathrm{c}_{1} \times \mathrm{Y}_{1}\right)+\left(\mathrm{g}_{1} \times \mathrm{c}_{2} \times \mathrm{Y}_{2}\right)\right] / \mathrm{g}_{1} \times 100 \%
\end{gathered}
$$

where $c_{1}$ is the weight fraction of SPL-1cut in the mixed sample, $c_{2}$ is the weight fraction of dolomite in the mixed sample, $Y_{1}$ is the loss ratio when SPL-1cut is separately processed, $Y_{2}$ is the loss ratio when dolomite is separately processed, and $\mathrm{Y}_{3}$ is the loss ratio when the first decomposition step of dolomite occurs-that is, only the $\mathrm{MgCO}_{3}$ in dolomite is completely decomposed into $\mathrm{MgO}$.

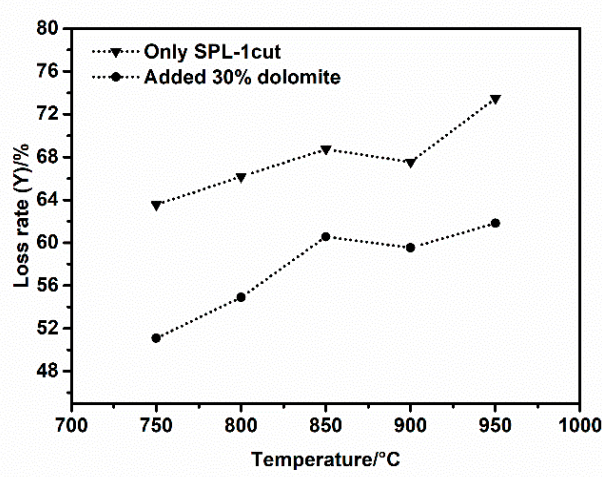

(a)

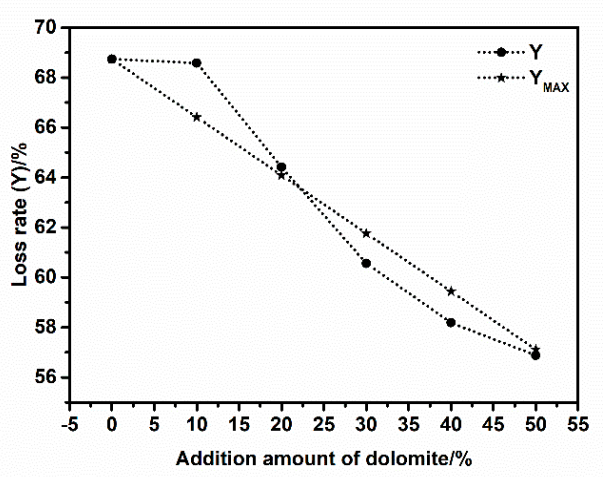

(c)

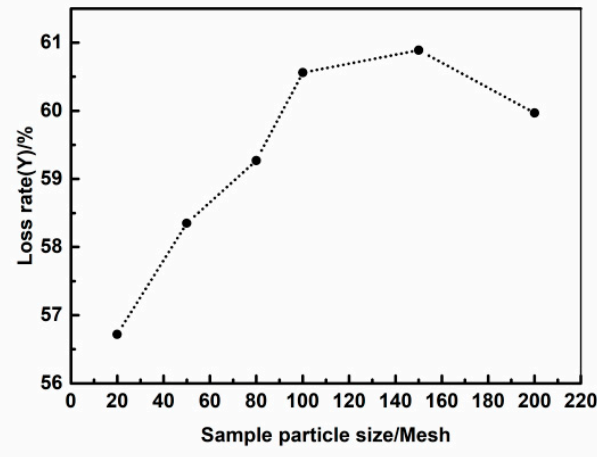

(b)

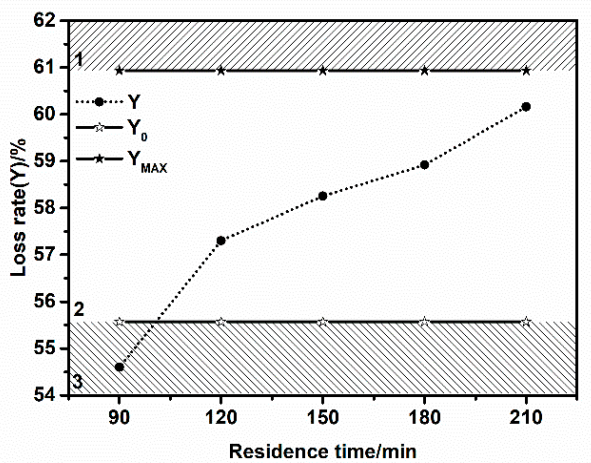

(d)

Figure 3. Trend of reaction loss ratio under different experimental conditions ((a) $100 \mathrm{mesh}, 30 \mathrm{wt} \%$ dolomite, $180 \mathrm{~min}$; (b) $850{ }^{\circ} \mathrm{C}, 30 \mathrm{wt} \%$ dolomite, $180 \mathrm{~min}$; (c) $850{ }^{\circ} \mathrm{C}, 100 \mathrm{mesh}, 180 \mathrm{~min}$; (d) $850{ }^{\circ} \mathrm{C}, 40$ wt $\%$ dolomite, 100 mesh).

It can be seen clearly from Figure 3a that the loss ratio of SPL-1cut reaches a steady state at $850{ }^{\circ} \mathrm{C}$. When the temperature rises to $900^{\circ} \mathrm{C}$, the electrolyte components in the SPL-1cut become eutectic and cause the mixture to become sticky, resulting in the insufficient combustion of the carbon in SPL-1cut, and the loss ratio decreases slightly. When the temperature is increased to $950{ }^{\circ} \mathrm{C}$, the low-melting-point electrolyte component in SPL-1cut may decompose and generate volatile loss, resulting in a large increase in the loss ratio. The loss ratio change trend of the experimental sample mixed with $30 \mathrm{wt} \%$ dolomite is similar to that of SPL-1cut burned alone, and is basically stable at $850{ }^{\circ} \mathrm{C}$. The melting point of $\mathrm{Na}_{2} \mathrm{CO}_{3}$ in the reaction product is $851{ }^{\circ} \mathrm{C}$. At $900{ }^{\circ} \mathrm{C}, \mathrm{Na}_{2} \mathrm{CO}_{3}$ easily melts and the mixture becomes sticky, causing a small decrease in the loss ratio. The addition of dolomite achieves the purpose of converting fluoride into $\mathrm{CaF}_{2}$, and prevents a large increase in the loss ratio when the 
temperature is up to $950{ }^{\circ} \mathrm{C}$. However, due to the inadequate amount of dolomite, the fluoride was not completely converted.

The loss ratio of the experimental sample becomes larger and larger when the particle size of the sample becomes finer and finer. The maximum value can be obtained when the particle size of the sample is finer than 150 mesh. As the particle size continues to become finer than 200 mesh, the loss ratio significantly decreases (as shown in Figure 3b). The reason for this phenomenon is that over-fine samples are much more likely to cause adhesion and agglomeration at a high temperature, which causes negative effects on all reactions and then reduces the loss ratio. The particle size of SPL-1cut has a certain influence on the subsequent treatment reaction. Similar to the size effect and the quantum confinement effect of materials, it has been widely studied and applied in the field of nano materials [18-20].

As shown in Figure 3c, the actual loss ratio $\mathrm{Y}$ in the upper left part of the graph is greater than $\mathrm{Y}_{\mathrm{MAX}}$. In this region, SPL-1cut and dolomite did not react or incompletely reacted, and the amount of dolomite added was insufficient. In the lower right part of the graph, the actual loss ratio $\mathrm{Y}$ is less than the maximum loss ratio $\mathrm{Y}_{\mathrm{MAX}}$. In this area, the SPL-1cut reacted with the dolomite and the reaction finished completely.

The fixed experimental conditions in Figure $3 \mathrm{~d}$ were that the temperature was $850{ }^{\circ} \mathrm{C}$, the particle size was less than 100 mesh, and the dolomite weight ratio was $40 \mathrm{wt} \%$. According to the change trend of reactions in Figure 3d, it can be divided into three areas: area 1, no reactions between the SPL-1cut and dolomite; area 2, the carbon in SPL-1cut burned completely, the $\mathrm{MgCO}_{3}$ in the dolomite also decomposed completely, and the reaction between fluoride and $\mathrm{CaCO}_{3}$ was thoroughly completed; area 3, the reaction was incomplete. During the processing of SPL-1cut, all reactions will be more thorough when the actual loss ratio $Y$ is between $Y_{0}$ and $Y_{\text {MAX }}$.

\section{Discussion}

XRD and SEM-EDS were used to analyze the final product, which was produced at $850{ }^{\circ} \mathrm{C}$ by keeping the sample size finer than 100 mesh, the dolomite addition ratio at $40 \mathrm{wt} \%$, and the residence time at $120 \mathrm{~min}$. The results are shown in Figures 4 and 5.

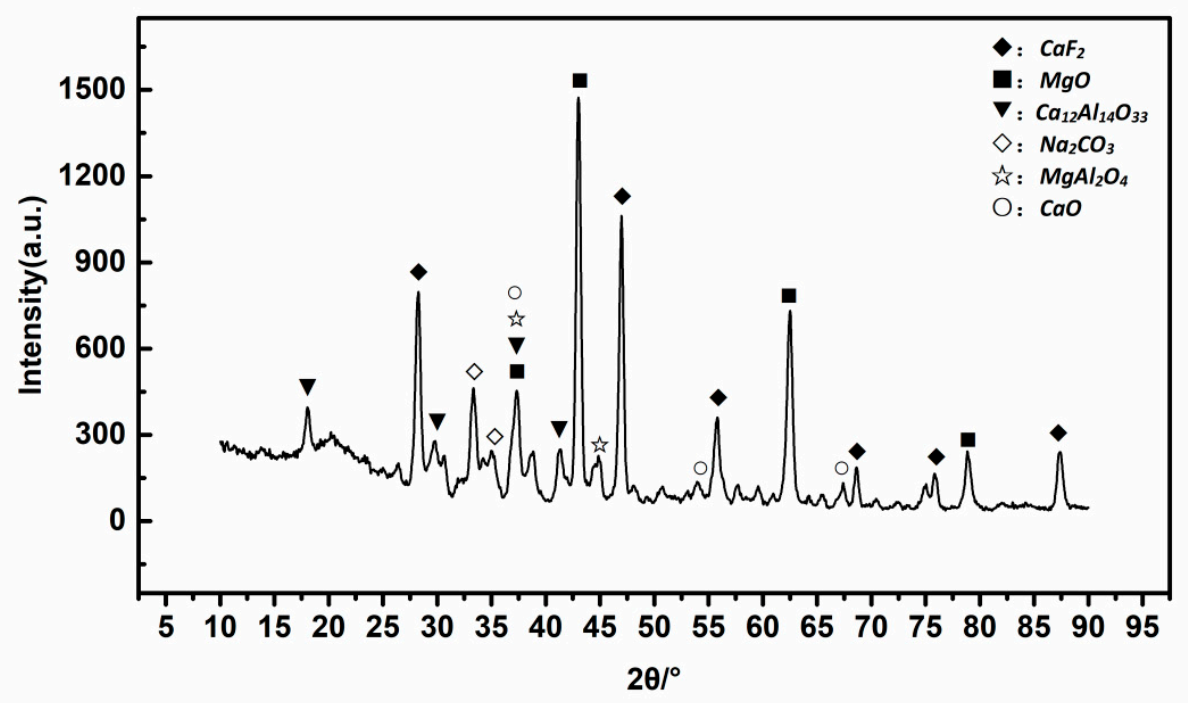

Figure 4. XRD pattern of the final product. 


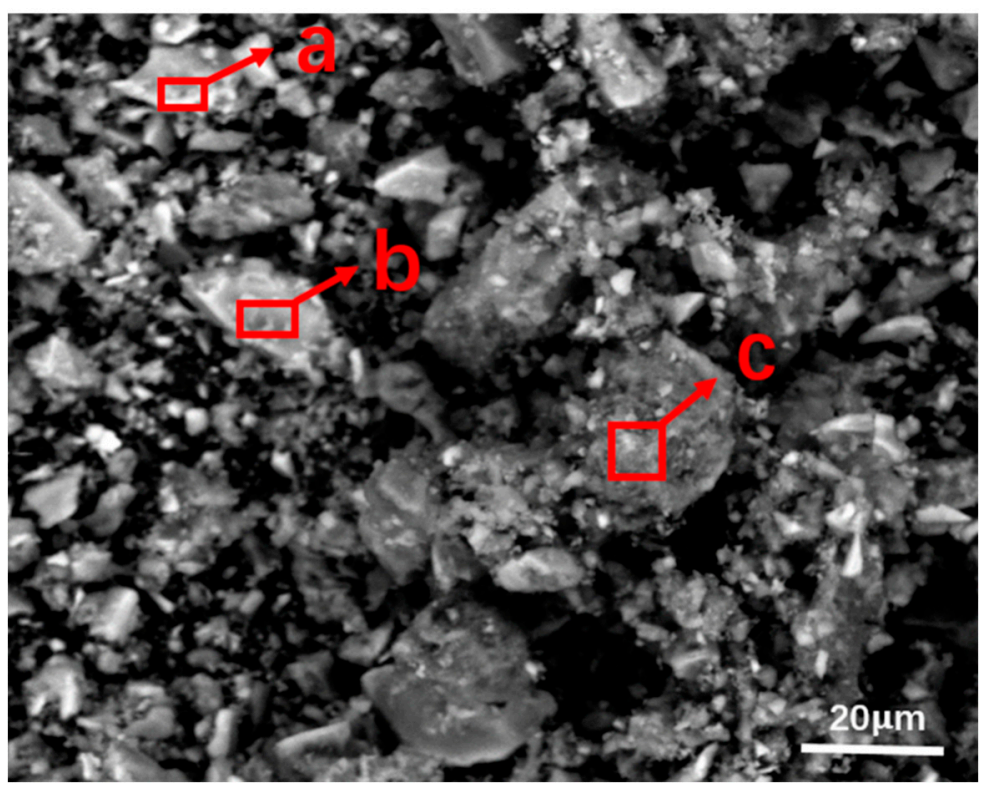

Figure 5. SEM-EDS analysis of the final product. Micro area (a) shows conversion reaction of fluoride; micro area (b) shows complete conversion of fluoride; micro area (c) shows dolomite decomposition.

(1) EDS analysis of different positions of the final product (wt $\%)$.

\begin{tabular}{cccccccccc}
\hline Elements & $\mathbf{C}$ & $\mathbf{F}$ & $\mathbf{N a}$ & $\mathbf{O}$ & $\mathbf{C a}$ & $\mathbf{M g}$ & $\mathbf{A l}$ & $\mathbf{K}$ & $\mathbf{S i}$ \\
\hline $\mathbf{a}$ & 6.75 & 6.81 & 9.52 & 32.42 & 28.05 & 1.09 & 6.48 & & 8.9 \\
$\mathbf{b}$ & 4.87 & 18.46 & 17.16 & 21.5 & 26.61 & 0.65 & 0.7 & 0.31 & 9.72 \\
$\mathbf{c}$ & 9.42 & 15.77 & 11.48 & 29.94 & 2.69 & 26.59 & 1.34 & 0.78 & \\
\hline
\end{tabular}

(2) EDS analysis of different positions of the final product $(\mathrm{At} \%)$.

\begin{tabular}{cccccccccc}
\hline Elements & $\mathbf{C}$ & $\mathbf{F}$ & $\mathbf{N a}$ & $\mathbf{O}$ & $\mathbf{C a}$ & $\mathbf{M g}$ & $\mathbf{A l}$ & $\mathbf{K}$ & $\mathbf{S i}$ \\
\hline $\mathbf{a}$ & 12.05 & 7.69 & 8.88 & 43.47 & 15.01 & 0.96 & 5.15 & & 6.8 \\
$\mathbf{b}$ & 8.93 & 21.41 & 16.45 & 29.61 & 14.63 & 0.59 & 0.57 & 0.18 & 7.63 \\
$\mathbf{c}$ & 14.8 & 15.67 & 9.43 & 35.32 & 1.27 & 22.2 & 0.93 & 0.38 & \\
\hline
\end{tabular}

$\mathrm{MgCO}_{3} \cdot \mathrm{CaCO}_{3}$ in dolomite exists in a double salt form whose high-temperature decomposition process can be divided into two steps. The decomposition of $\mathrm{MgCO}_{3}$ occurs first, and then $\mathrm{CaCO}_{3}$ decomposition occurs. This characteristic of dolomite ensures that it can provide effective, active $\mathrm{CaCO}_{3}$ as a reactant when reacting with fluorides in SPL-1cut. It can be clearly seen from Figure 4 that the final product mainly consists of $\mathrm{CaF}_{2}$ and $\mathrm{MgO}$. In Figure 5, area a is a conversion reaction place of fluoride, and its main substances are $\mathrm{CaCO}_{3}$ and NaF; area $\mathrm{b}$ is a complete conversion place of fluoride, and its main substances are $\mathrm{CaF}_{2}$ and $\mathrm{Na}_{2} \mathrm{CO}_{3}$; the main substances in area $\mathrm{c}$ are $\mathrm{MgO}$ and $\mathrm{NaF}$, and the first step of dolomite decomposition occurred in this area. During thermal processing, $\mathrm{MgCO}_{3} \cdot \mathrm{CaCO}_{3}$ in dolomite was decomposed to generate $\mathrm{MgO}$ and $\mathrm{CaCO}_{3}$, and the newly generated $\mathrm{CaCO}_{3}$ reacted with $\mathrm{NaF}$ to ensure the conversion of fluorides. Furthermore, along with the temperature rises, carbon combustion, and dolomite first-step decomposition, reactions between fluorides and calcium carbonate occur in turn. When dolomite is used to treat SPL-1cut, the final product containing MgO and $\mathrm{CaF}_{2}$ can be more easily recycled in the Pidgeon Process. The process has more practical value compared with the previous process, which used limestone.

When the SPL-1cut was processed for 120 min under the conditions of $850^{\circ} \mathrm{C}$, particle size finer than 100 mesh, and a dolomite addition fraction at $40 \mathrm{wt} \%$, the complete conversion of fluorides was 
achieved by fluorides reacting with newly generated $\mathrm{CaCO}_{3}$. At the same time, the $\mathrm{MgCO}_{3}$ in dolomite was decomposed into $\mathrm{MgO}$. In a word, the processing of SPL-1cut is feasible by adding dolomite. The process has the following advantages: the temperature is not high, the concentration of soluble fluoride in the final product can be reduced to a safe limit, and the final product does not show an obvious adhesion phenomenon.

The leaching toxicity of the SPL-1cut final product (treated with dolomite) was measured, and the results are listed in Table 4.

Table 4. Leaching toxicity of the SPL-1cut final product treated with dolomite $\left(\mathrm{mg} \cdot \mathrm{L}^{-1}\right)$.

\begin{tabular}{ccc}
\hline Parallel Samples & $\mathbf{F}^{-}$ & $\mathbf{C N}^{-}$ \\
\hline $\mathbf{1}$ & 47.53 & 0.047 \\
$\mathbf{2}$ & 49.83 & 0.051 \\
$\mathbf{3}$ & 48.37 & 0.048 \\
\hline
\end{tabular}

It can be seen from Table 4 that $\mathrm{F}^{-}$and $\mathrm{CN}^{-}$in the final product are lower than the national limit (GB5085.3-2007) [21].

\section{Conclusions}

The recycling of SPL-1cut is achieved by adding dolomite to SPL-1cut based on the characteristics of the two-step decomposition of dolomite at high temperatures. During the thermal process, the $\mathrm{CaCO}_{3}$ newly generated by the first-step decomposition of dolomite will react with fluorides to generate calcium fluoride, an insoluble fluoride. The cyanides will be completely oxidized and decomposed. The exothermic combustion of carbon provides enough heat for other reactions.

Dolomite is used as a reactant to reduce the soluble fluorides in SPL-1cut. The final product is mainly composed of $\mathrm{MgO}$ and $\mathrm{CaF}_{2}$. It can be used as a raw material and as an alternative fuel for magnesium production by the Pidgeon Process so as to save fluorite and standard coal.

The recycling feasibility of SPL-1cut in magnesium production by the silicon thermal process is discussed in this paper, and some preliminary results were obtained. In the future, continuous research will be conducted on the following aspects: the addition of SPL-1cut instead of standard coal for the dolomite calcination process, including the blending ratio of SPL-1cut, and the influences of SPL-1cut on the magnesium reduction tank and magnesium yield.

Author Contributions: Conceptualization, Y.W., X.C., and S.Z.; methodology, X.C. and S.Z.; formal analysis, Y.W.; investigation, Y.W.; resources, X.C. and S.Z.; writing—original draft preparation, Y.W.; writing-review and editing, X.C.; supervision, P.Y.; project administration, P.Y. All authors have read and agreed to the published version of the manuscript.

Funding: This research was supported by a grant from the National Key Research and Development Plan of China under grant no. 2016YFB0301001 and 2016YFB0301101.

Acknowledgments: The authors would especially like to thank Jiang Du and Jinhui Liu for their help in this research.

Conflicts of Interest: The authors declare no conflict of interest.

\section{References}

1. Breault, R.; Poirier, S.; Hamel, G.; Pucci, A. A 'green' way to deal with spent potlining. Alum. Int. Today 2011, 23, 22-24.

2. Holywell, G.; Breault, R. An overview of useful methods to treat, recover, or recycle spent potlining. JOM 2013, 65, 1441. [CrossRef]

3. Sustainable Spent Potlining Management Guidance. Available online: http://www.world-aluminium.org/ media/filer_public/2020/02/28/final_spl_guidance_-_25_feb_2020.pdf (accessed on 25 February 2020).

4. Zhai, X.; Qiu, Z. The treatment of spent pot lning. Environ. Chem. 1993, 12, 139. 
5. Chauke, L.; Garbers-Craig, A.M. Reactivity between carbon cathode materials and electrolyte based on industrial and laboratory data. Carbon 2013, 58, 40-45. [CrossRef]

6. Blayden, L.C.; Epstein, S.G. Spent potlining symposium. JOM 1984, 36, 22. [CrossRef]

7. Byers, R.L.; Epstein, S.G. Spent potlining update. JOM 1986, 11, 34. [CrossRef]

8. Jia, G.; Du, J. Catalyst-Assisted Solution-Liquid-Solid Synthesis of CdS/CuInSe 2 and CuInTe $2 / \mathrm{CuInSe}_{2}$ Nanorod Heterostructures. Inorg. Chem. 2018, 58, 695-702. [CrossRef] [PubMed]

9. Jia, G.; Wang, C.; Yang, P.; Liu, J.; Zhang, W.; Li, R.; Zhang, S.; Du, J. Sulfur-free synthesis of size tunable rickardite $\left(\mathrm{Cu}_{3-\mathrm{x}} \mathrm{Te}_{2}\right)$ spheroids and planar squares. R. Soc. Open Sci. 2019, 6, 181602. [CrossRef] [PubMed]

10. Wang, K.; Liu, B.; Yang, P.; Liu, J.; Zhang, W.; Wang, C.; Lu, H.; Jia, G.; Li, R.; Zhang, S.; et al. One-pot synthesis of branched CuInSe2 nanowires based on solution-liquid-solid method and their implementation in photovoltaic devices. J. Cryst. Growth 2019, 52, 125152. [CrossRef]

11. Courbariaux, Y.; Chaouki, J.; Guy, C. Update on Spent Potliners Treatments: Kinetics of Cyanides Destruction at High Temperature. Ind. Eng. Chem. Res. 2004, 43, 5828. [CrossRef]

12. Deutschman, J.E.; Johnson, D.O.; Lobos, J.S.; Reid, A.S. A process to produce from potlining an inert residue suitable for landfill sites. Light Met. 1987, 669-675.

13. Banker, D.B.; Ark, L.R.; Brooks, D.G.; Cutshall, F.R.E.; Strahan, D.F. Detoxification of Aluminum Spent Polining by Thermal Trertment, Lime Slurry Quench and Post-Kiln Treatment. U.S. Patent 5,164,174, 1992.

14. Li, W.; Chen, X. Development Status of Processing Technology for Spent Potlining in China. In Light Metals; Springer: Berlin/Heidelberg, Germany, 2013; pp. 1064-1066.

15. Goldsmith, J.R.; Graf, D.L. The mineralogical composition of the calcareous corpuscles of Taenia taeniaeformis. J. Geol. 1958, 66, 678-693. [CrossRef]

16. Bandi, W.R.; Krapf, G. The effect of $\mathrm{CO}_{2}$ pressure and alkali salt on the mechanism of decomposition of dolomite. Thermochim. Acta 1976, 14, 221-243. [CrossRef]

17. Samtani, M.; Dollimore, D.; Wilburn, F.W.; Alexander, K. Isolation and identification of the intermediate and final products in the thermal decomposition of dolomite in an atmosphere of carbon dioxide. Thermochim. Acta 2001, 367-368, 285-295. [CrossRef]

18. Jia, G.; Du, J. Foreign Metal Ions to Control the Morphology of Solution-Liquid-Solid Reaction. Cryst. Growth Des. 2018, 18, 7489-7495. [CrossRef]

19. Jia, G.; Du, J. Solution-Liquid-Solid Growth of CuInTe 2 and CuInSe $\mathrm{Te}_{2-\mathrm{x}}$ Semiconductor Nanowires. Inorg. Chem. 2018, 57, 14961-14966. [CrossRef] [PubMed]

20. Jia, G.; Liu, B.; Wang, K.; Wang, C.; Yang, P.; Liu, J.; Zhang, W.; Li, R.; Zhang, S.; Chengduo, W. $\mathrm{CuInTe}_{2}$ Nanocrystals: Shape and Size Control, Formation Mechanism and Application, and Use as Photovoltaics. Nanomaterials 2019, 9, 409. [CrossRef] [PubMed]

21. Identification Standards for Hazardous Wastes-Identification for Extraction Toxicity; Chinese National Standard. GB 5085.3-2007; China Environmental Science Press: Beijing, China, 2007.

Publisher's Note: MDPI stays neutral with regard to jurisdictional claims in published maps and institutional affiliations.

(C) 2020 by the authors. Licensee MDPI, Basel, Switzerland. This article is an open access article distributed under the terms and conditions of the Creative Commons Attribution (CC BY) license (http://creativecommons.org/licenses/by/4.0/). 